\title{
A MODEST PROPOSAL FOR SECURITIES FRAUD PLEADING AFTER TELLABS
}

\author{
GEOFFREY MILLER* \\ I \\ INTRODUCTION
}

Pleading rules are filters. They weed out some cases while allowing others to go forward. By controlling access to the litigation system, these rules-if they function as intended-can reduce burdens on the courts, save parties from having to defend themselves against baseless charges, and facilitate the fair and efficient administration of justice.

All pleading rules face the problem of error. Because decisions are made before the facts are determined, courts make mistakes in their projections about how the case will develop. As with any filter, the errors come in two types. Some cases that should not continue are allowed through, and some cases that ought to be litigated are weeded out. Ideally, pleading rules should be designed so as to minimize the joint cost of the two error types. Judges and rulemakers are like legal engineers responsible for designing systems that solve this optimization problem.

Tellabs, Inc. v. Makor Issues \& Rights, Ltd. ${ }^{1}$ is a signal example of a pleading rule as filter. The Private Securities Litigation Reform Act (PSLRA) declares that

in any private action arising under this title in which the plaintiff may recover money damages only on proof that the defendant acted with a particular state of mind, the complaint shall, with respect to each act or omission alleged to violate this title, state with particularity facts giving rise to a strong inference that the defendant acted with the required state of mind.

If a complaint does not satisfy the requirements set forth in the statute, the case will be dismissed (although the court may declare that the dismissal is without prejudice, thus allowing the plaintiff to re-plead). The PSLRA is therefore a filter: complaints that satisfy the rule go forward; ones that do not are eliminated.

Tellabs concerned the interpretation of this pleading requirement. It set forth a uniform federal standard for determining when allegations in a securities fraud complaint suffice to create a strong inference of scienter (the technical term for the state of mind required to establish liability for securities fraud). In

Copyright () 2012 by Geoffrey Miller.

This article is also available at http://www.law.duke.edu/journals/lcp.

* Stuyvesant Comfort Professor of Law, New York University.

1. 551 U.S. 308, 313 (2007).

2. 15 U.S.C. $\S 78 \mathrm{u}-4(\mathrm{~b})(2)(\mathrm{A})$ (2006) (amended 2010). 
the Court's now-familiar articulation, a securities fraud complaint will survive a motion to dismiss if and "only if a reasonable person would deem the inference of scienter cogent and at least as compelling as any opposing inference one could draw from the facts alleged.",3

Does the PSLRA, as interpreted in Tellabs, draw the most effective line for weeding out meritless securities fraud suits while allowing meritorious ones to proceed? This article considers that question. This article presents the argument that although Tellabs represents a creditable effort to clarify imprecise statutory language and to implement the intent of Congress, the rule articulated by the Court falls short in several respects.

\section{II}

\section{INTERPRETING TELLABS}

Tellabs clarified the law in several respects. First, it articulated a uniform standard for scienter allegations in securities fraud complaints, thereby resolving pre-existing disagreements among the federal circuits. ${ }^{4}$ Second, it established that the test is comparative in the sense that a court must evaluate both culpable and non-culpable inferences that could be drawn from the facts alleged. ${ }^{5}$ Third, Tellabs indicated that ties go to the plaintiff: the plaintiff does not need to show that the inference of scienter is the most plausible one to be drawn from the facts pled in the complaint, only that it is at least as plausible as other inferences. ${ }^{6}$ Finally, Tellabs established a middle-ground approach toward scienter pleadings. The Court made it clear that it was opting for neither the stringent standards that some circuits had developed, nor for the lenient ones that others had.

Even though Tellabs clarified the law in these respects, the standard articulated by the Court was itself subject to ambiguity. First, the key language appeared to support two possible interpretations. The first interpretation sees the test as bifurcated: the inference of scienter must be both (1) cogent, in the sense that it meets a baseline level of plausibility; and (2) at least as compelling as any of one or more innocent inferences. There are a number of arguments for a bifurcated rule. First, although the Court did not say it was crafting a bifurcated test, its language implies as much: it indicated that the inference of scienter must be both cogent and at least as compelling as any innocent inferences. Given that the language was carefully crafted, it would seem plausible to conclude that two things are required. Second, the bifurcated test supplies independent content to the term "cogent," namely a requirement that the complaint satisfy a baseline level of plausibility. Third, the bifurcated construction accounts for the Court's comment that the inference of scienter

\footnotetext{
3. 551 U.S. at 324.

4. Id. at 313-14.

5. Id. at 314 .

6. Id.; see also Helwig v. Vencor, Inc., 251 F.3d 540 (6th Cir. 2001) (en banc).

7. Id.
} 
must be as compelling as "any" opposing inference; it allows for the possibility that there will be more than one innocent inference. Finally, the bifurcated interpretation gives separate meaning to both parts of the test. If multiple innocent explanations could be provided for the facts alleged, and if the inference of scienter need only be as strong as the strongest of these inferences, then the test can be satisfied, in some cases, by low-probability inferences of scienter. ${ }^{8}$ But it might not be desirable to allow the case to go forward in such a case because the plaintiff's claim is weak relative to the aggregate of innocent explanations. The "cogency" test deals with this problem by requiring that, in addition to satisfying the comparative standard, the inference of scienter must also satisfy a baseline level of plausibility.

The alternative, unitary interpretation sees Tellabs as setting forth a simple rule: to survive a motion to dismiss, the allegations must be such that the inference that the defendant acted with scienter is at least as strong as the inference that the defendant did not act with scienter. ${ }^{9}$ A number of arguments favor the unitary approach. It is simple and straightforward to apply. It aligns reasonably well with the issue that must be resolved at trial-not perfectly, because under Tellabs ties go to the plaintiff whereas at trial they go to the defendant, but still close enough. A unitary rule, moreover, can claim support in the Court's language. The Court never announced, as it often does, that it was formulating a two-part test or that the plaintiff must satisfy each prong of a standard. True, the requirement that the inference of scienter must be "cogent and at least as compelling" might be read to suggest that two requirements must be met, but this language might also be seen as a kind of rhetorical flourishmuch as, in the view of some, the term "necessary and proper" in the Constitution does not imply that separate meaning must be given to each of those terms. ${ }^{10}$

This doctrinal thicket may appear barren and technical, but there are real

8. Suppose, for example, that the complaint alleges that the defendant engaged in channelstuffing - pre-selling large amounts of product. The allegation of channel-stuffing gives rise to an inference of scienter because, by booking sales early, the defendant can inflate its profits for the reporting period. On the other hand, there may be innocent reasons why larger-than-usual amounts of product were sold. Perhaps the defendant underestimated the extent of demand. Perhaps the defendant was shifting production techniques and needed to offload inventory. Perhaps the excess sales came from a corrupt company officer whose actions were not known to the company or to the people making disclosure to the market. If the one inference of scienter and the three innocent explanations each have an equal probability of being true, then a plaintiff could argue that the second prong of the test was satisfied because the inference of scienter is at least as compelling as any innocent inference.

9. The Supreme Court has not held that recklessness is sufficient to establish scienter, but the lower federal courts agree that this mental state is sufficient. See Mansbach v. Prescott, Ball \& Turben, 598 F.2d 1017, 1023 (6th Cir. 1979) ("The overwhelming majority of courts to address this question ... have concluded that recklessness satisfies the $\S 10(\mathrm{~b}) /$ Rule 10b-5 scienter requirement.").

10. See Gary Lawson, Geoffrey P. Miller, Robert G. NATElson, \& Guy I. Seidman, The ORIGINS OF THE NECESSARY AND PROPER CLAUSE 159-74 (2010) (analyzing whether historical background supports the view that the terms are synonymous); See also United States v. Comstock, 130 S. Ct. 1949 (2010) (discussing background of Necessary and Proper Clause and analyzing the term as stating a single standard). 
consequences involved. The unitary test weeds out more complaints than the bifurcated test. The reason is that inferences of scienter with less than a fifty percent probability do not satisfy the unitary test but can, in theory, satisfy the bifurcated test as long as there are several innocent inferences and the culpable inference satisfies a baseline of plausibility. Thus, the bifurcated test is more plaintiff friendly and the unitary test is more favorable to the defense.

As Tellabs has emerged from its infancy, courts have addressed this ambiguity. They do so in the glosses they put on the Tellabs standard. The consensus of reported decisions is to go with the unitary approach. The courts deal with the inconvenience of the term "cogent" by simply forgetting that it exists. Perhaps the strongest evidence of this disregard is found in Merck \& Co., Inc. v. Reynolds, ${ }^{11}$ a 2010 Supreme Court decision. The case had nothing to do with scienter (it involved an interpretation of the discovery rule under the statute of limitations). Thus, the Court's observations were pure dicta. Nevertheless, even dicta is weighty when it comes from the Supreme Court. Justice Breyer, writing for the Court, characterized the Tellabs holding as follows: "unless a [securities fraud] plaintiff can set forth facts in the complaint showing that it is 'at least as likely as' not that the defendant acted with the relevant knowledge or intent, the claim will fail." ${ }^{12}$ This is not what the Tellabs Court said; Justice Breyer's paraphrase fails to mention the requirement of cogency and fails to repeat the language about "any competing inference." No matter: the paraphrase sends a signal about how the Supreme Court is likely to interpret Tellabs if it revisits the issue. The Merck case, to the extent its interpretation is viewed as authoritative, opts for the unitary interpretation of the Tellabs rule.

Lower courts have reached similar conclusions. An example is the Eleventh Circuit's decision in Durgin v. Mon. ${ }^{13}$ The court started by quoting the full Tellabs test, including the requirement of cogency. The court then subtly changed the test, however, observing that the inference of scienter must be "'at least as compelling as any opposing inference of' conduct that did not violate $\S$ 10(b)." "The term "cogent" was forgotten and did not play a role in the court's analysis. ${ }^{15}$ Durgin appears to represent the consensus of federal courts in this respect. ${ }^{16}$ Accordingly, we may conclude, at least tentatively, that one potential interpretative dilemma has now been resolved: Tellabs adopts a unitary rather than a bifurcated standard.

A second ambiguity in Tellabs concerned the issue of whose judgment controls the analysis. The language of the test requires that a complaint must

11. 130 S. Ct. 1784 (2010).

12. Id. at 1796 (quoting Tellabs, 551 U.S. at 328).

13. 415 F. App'x 161 (11th Cir. 2011).

14. Id. at 166 (quoting Tellabs, 551 U.S. at 314).

15. Id.

16. For the most important example, see the Supreme Court's recent treatment of the issue in Matrixx Initiatives, Inc. v. Siracusano. 131 S. Ct. 1309, 1324 (2011) (analyzing the term "cogent and at least as compelling" as a single standard). 
allege facts from which "a reasonable person would" deem the inference of scienter cogent and at least as compelling as any opposing inference." ${ }^{17}$ What is the meaning of "would" in this sentence? Perhaps the standard requires the court to draw its own inferences. Or perhaps the court should look to inferences of a reasonable person. These interpretations are different: it is possible that a court, applying its own judgment, would conclude that the facts alleged do support a strong inference of scienter, while still accepting that a reasonable person could conclude that the facts do not support a strong inference of scienter. The standard that looks to the court's own judgment is more favorable to plaintiffs than the standard that looks to the range of judgments that could be reached by a reasonable person. A review of a sample of recorded decisions suggests that, in practice, the courts are using the first of these approaches. ${ }^{18} \mathrm{On}$ this question, therefore, the courts have opted for the more plaintiff-friendly position.

Accordingly, now that Tellabs is out of swaddling clothes, we can discern a mature doctrine: the court must decide whether, taking as true the facts alleged, it is at least as likely as not that the defendant acted with scienter.

III

EVALUATION

Tellabs displays a number of commendable features. It represents a goodfaith effort to give discernible content to the congressional language and to provide helpful guidance to lower courts. It articulates a uniform federal standard, replacing the balkanized formulations that had developed among the courts of appeals. As refined by later decisions, the doctrine is simple and workable. And the Court struggled to accommodate the wishes of Congress in enacting the PSLRA. All this is much to the Court's credit.

Empirical research, moreover, suggests that Tellabs achieved the goal of establishing a middle ground between stringent and lenient pleading requirements. Stephen Choi and Adam Pritchard studied the effect of Tellabs on a sample of securities fraud class actions decided between 2003 and 2007 by comparing the results of motions to dismiss filed before and after the decision. ${ }^{19}$ They found that the dismissal rate on scienter grounds post-Tellabs was significantly lower in jurisdictions that had previously adopted a stringent standard and higher (although not significantly so) in circuits that had previously applied a lenient standard. ${ }^{20}$ Choi and Pritchard also found an effect

17. Tellabs, 551 U.S. at 324 (emphasis added).

18. See, e.g., City Of Dearborn Heights v. Waters Corp., 632 F.3d 751, 758-62 (1st Cir. 2011); Dronsejko v. Thornton, 632 F.3d 658, 666-70 (10th Cir. 2011); Edward J. Goodman Life Income Trust v. Jabil Circuit, Inc., 594 F.3d 783, 791-93 (11th Cir. 2010); In re Bank of Am. Corp., 2011 WL 740902, at $* 13$ (N.D. Cal. Feb. 24, 2011).

19. Stephen Choi \& Adam Pritchard, The Supreme Court's Impact on Securities Class Actions: An Empirical Assessment of Tellabs 2-4 (NYU Center for Law, Economics and Organization, Working Paper No. 09-34, (draft of June 23, 2011)).

20. Id. at 18-19. They also found that judges who have substantial business caseloads or who were 
on settlement. Circuits previously employing a stringent standard experienced a higher incidence of low-value settlements post-Tellabs, while circuits that had previously adopted a lenient standard experienced a decrease in low-value settlements (although, again, the decrease was not significant). ${ }^{21}$ Overall, the study supports the idea that Tellabs achieved its intended effect of tightening pleading standards in lenient circuits and loosening them in strict ones.

Despite these admirable features, there are also grounds for critiquing the Tellabs decision. First, it is far from clear that the issue that so concerned the members of Congress who supported the PSLRA is really much of a problem. The two goals of Congress, the Tellabs Court said, were "to curb frivolous, lawyer-driven litigation, while preserving investors' ability to recover on meritorious claims." ${ }^{22}$ Consider the rhetoric here. The Tellabs Court, channeling Congress, contrasts two types of securities litigation. One, the "good" type, involves meritorious claims and the interest of investors. The Court's description of good securities litigation is couched in language that is measured, sedate, and dignified. Lawyers are not mentioned; they are obviously present, but behind the scenes, performing their proper role as officers of the court and fiduciaries of their clients. Good securities fraud litigation is orderly, respectful, and compliant with the norms of client service and proper professional conduct.

The other, "bad" type of securities fraud litigation is "frivolous" and "lawyer-driven." This language is heated, inflated, and emotional. "Lawyerdriven" evokes ideas of champerty, barratry, and maintenance; the suggestion is that something must be done to protect society against attorneys who stir up litigation. "Frivolous" evokes the image of the extortionate, meritless lawsuit, brought solely to extract a settlement offer. By linking lawyer-driven and frivolous litigation, the slogan suggests that when lawyers drive the cases, the results are frivolous suits benefiting no one other than the attorneys themselves.

All this is heady stuff. It plays well in congressional debates and town meetings. The problem is that it bears little relationship to reality. Consider first the idea of "lawyer-driven" litigation. The catchphrase recited by the Court suggests that lawyer-driven litigation is frivolous litigation. The fact of the matter, however, is that all plaintiffs' securities litigation is lawyer-drivenfrivolous or not. Plaintiffs' attorneys bring these cases on a contingency basis. They recover fees only if the case generates a favorable judgment or settlement. Otherwise they lose their investments of time and resources. Having a strong interest in the outcome, lawyers naturally are a force in driving it forward. Attorneys, in fact, do exercise an important influence from soup to nutsidentifying claims, devising legal theories, and making key litigation decisions. The PSLRA attempted to reduce the level of attorney influence by preferring the lead plaintiff candidate who has the largest financial stake in the litigation. Even so, plaintiffs' attorneys continue to drive these cases. And this goes for

nominated by Republican presidents became less likely to dismiss on scienter grounds after Tellabs. Id.

21. Id.

22. Tellabs, 551 U.S. at 322. 
"good" securities fraud cases as well as "bad" ones.

Equally questionable is the suggestion that plaintiffs' lawyers like to bring frivolous lawsuits. There is no reason to suppose that this is the case. Plaintiffs' counsel would prefer a strong case to a weak one, other things equal, since strong cases have greater settlement potential. Further, plaintiffs' attorneys are subject to Rule 11 of the Federal Rules of Civil Procedure, which imposes a duty not to file pleadings that have no sound basis in fact or law. ${ }^{23}$ All attorneys, moreover, are bound by ethics codes requiring candor and fair dealing towards the tribunal and opposing parties. ${ }^{24}$ The notion of "frivolous, lawyer-driven" 25 litigation suggests that plaintiffs' attorneys are less constrained by these niceties than are their counterparts in the defense bar. There is no evidence to support this stereotype. It is true that plaintiffs' attorneys do not always behave ethically, and it is also true that some leading members of the plaintiffs' bar have behaved badly in recent years; but defense counsel are not paragons of virtue either. At least in my experience, plaintiffs' class action attorneys display a high degree of professionalism and integrity. There is little other than prejudice to suggest that one type of lawyer is any better or more ethical than the other.

Consider now the reason why frivolous litigation is supposed to be a concern: the blackmail lawsuit brought solely to extract a settlement offer. Despite the perception that, prior to the PSLRA, securities fraud litigation was rampant with such abuse, evidence on this point is much in dispute. One wellknown study from 1991 suggested that settlements in securities fraud class actions were unrelated to the merits-implying that defendants were settling cases, regardless of their merit, out of fear of devastating erroneous judgments or out of desire to avoid the expense and harassment of litigation. ${ }^{26}$ The idea that the merits do not matter for purposes of securities fraud settlements has been questioned on theoretical and empirical grounds in the years since the 1991 study appeared. ${ }^{27}$ For example, the observed settlement values could reflect a conventional understanding of the anticipated judgments in securities fraud litigation, taking account of the merits. If these values become a focal point for negotiation, it would not be surprising that they show up in actual settlement data.

23. FED R. CIV. P. 11(b)(2)-(4).

24. See, e.g., Model RUles OF PROF'L CONDUCT R. 3.3 (2004) (prohibiting a lawyer from, among other things, "mak[ing] a false statement of fact or law to a tribunal").

25. Tellabs, 551 U.S. at 322.

26. Janet Cooper Alexander, Do the Merits Matter? A Study of Settlements in Securities Class Actions, 43 STAN. L. REV. 497, 596-97 (1991).

27. See generally, Tom Baker \& Sean J. Griffith, How the Merits Matter: D\&O Insurance and Securities Settlements, 157 U. PA. L. REV. 755 (2009); Adam C. Pritchard, Karen K. Nelson \& Marilyn F. Johnson, Do the Merits Matter More? The Impact of the Private Securities Litigation Reform Act, 23 J.L. ECON. \& ORG. 627 (2007); Stephen J. Choi, Do the Merits Matter Less After the Private Securities Litigation Reform Act?, 23 J.L. ECON. \& ORG. 598 (2007). On "blackmail" settlements, see generally Charles Silver, "We're Scared to Death": Class Certification and Blackmail, 78 N.Y.U. L. REV. 1357 (2003). 
Accordingly, there is good reason to doubt that, prior to the PSLRA, the federal courts were plagued by frivolous securities class actions. But suppose that frivolous claims were in fact a problem for securities fraud litigation. Is the PSLRA's "strong inference" standard, as refined in Tellabs, a sensible means to deal with the issue? Recall that this is a filter designed to strain out undesirable cases while allowing desirable ones to proceed. The value of any filter is judged by its success in minimizing the sum of the error costs-the costs of erroneously blocking desirable claims and failing to block undesirable ones.

The PSLRA's strong pleading standard, as interpreted in Tellabs, does a fine job at minimizing the second of these costs. The requirement that the inference of scienter must be cogent and at least as compelling as any competing inference is stringent enough that it would be difficult for a plaintiffs' attorney with a frivolous claim to get through. There is, accordingly, no obvious problem with this type of error.

The problem with the Tellabs standard, however, lies in its susceptibility to the other type of error. Although the standard screens out frivolous claims, it also rejects claims that are not frivolous. The complaint is filed at the outset of the litigation when all the facts are not known. It is difficult for a plaintiff at this stage to identify specific facts giving rise to a strong inference of scienter, as required under the PSLRA. ${ }^{28}$ Moreover, the private securities fraud plaintiff is at a special disadvantage due to the PSLRA's stay of discovery until the conclusion of motions to dismiss. ${ }^{29}$ The plaintiff's counsel is placed in the difficult posture of having to make detailed allegations giving rise to a strong inference of scienter without being allowed to conduct the discovery needed to uncover these facts. It stands to reason that in such circumstances a complaint might suffer dismissal, even though - if the matter were taken to trial- the plaintiff would wind up establishing the defendant's liability.

Stephen Choi examined this question in a pre-Tellabs study of initial public offerings from 1990 to 1999 and IPO-related securities-class-action litigation involving a mix of Section 11 and Rule 10b-5 antifraud claims. ${ }^{30}$ He found that non-nuisance claims lacking hard-evidence indicia of fraud, such as an accounting restatement or Securities and Exchange Commission action, faced a lower probability of suit and a greater likelihood of receiving a dismissal or lowvalue settlement in the post-PSLRA period. In other words, the PLSRA weeded out low-probability but nonfrivolous claims. ${ }^{31}$

There is no reason to believe that the Supreme Court's definition of the PSLRA's "strong inference" standard changed things in this regard. Even a cursory examination of cases dismissed under Tellabs reveals that many are not

28. 15 U.S.C. $\$ 78 u-4(b)(2)(A)$.

29. See id. § 78u-4(b)(3)(B) (automatically staying discovery except when the judge considers it necessary in order to preserve evidence or prevent prejudice).

30. Choi, supra note 27, at 598.

31. Id. 
frivolous. In Durgin v. Mon, ${ }^{32}$ to take one of many examples, the plaintiffs claimed that the defendants, senior executives of a homebuilding company, had fraudulently reported that a loan the company had obtained was without recourse when, in fact, the company had guaranteed repayment. ${ }^{33}$ The loan in question represented seventy percent of the company's net worth, and the company lacked the resources to repay in the event that the guarantee was triggered. $^{34}$ On these facts, the appellate court held that scienter had not properly been alleged since the complaint failed to state particularized facts indicating that the defendants knew the loan was with recourse..$^{35}$ The court rejected the plaintiffs' claim that the defendants, who included the company's chief executive officer and president, its chief financial officer, and its chief accounting officer, ${ }^{36}$ must have known that the company's financial statements and press releases were materially inaccurate and misleading regarding the recourse nature of the loan. ${ }^{37}$ Perhaps the court's ruling was correct as an application of the Tellabs test, but this serves to illustrate the problem. It is hardly farfetched to suppose that the senior officers knew the company's assets were pledged to satisfy the loan and that inconsistent representations had been made in the company's financial statements, press releases, and other disclosures. Moreover, these officials had a strong reason not to inform the market about the recourse nature of the loan because to do so would have reduced the company's attractiveness as an investment. There was nothing frivolous about this case. The effect of Tellabs was to dismiss an action where fraud might have been established if the plaintiff had been allowed to proceed to trial.

In Konkol v. Diebold, Inc., ${ }^{38}$ the plaintiffs alleged that the defendant, a manufacturer of voting machines, had-together with its senior managersengaged in schemes to inflate profits, including booking revenue for the sale of machines that did not comply with applicable law. ${ }^{39}$ The complaint alleged, among other things, that the individual defendants had access to detailed financial information revealing the fraudulent scheme; ${ }^{40}$ that some of these defendants had sold large amounts of the company's stock only weeks after false financial reports had driven the shares to an all-time high; ${ }^{41}$ that the accounting violations were substantial and pervasive; ${ }^{42}$ that confidential witnesses described the fraudulent scheme in detail and claimed that high-level

32. 415 F. App’x 161 (11th Cir. 2011).

33. Id. at 163 .

34. Id.

35. Id. at 165 .

36. Id. at 162 .

37. Id. at 165 .

38. 590 F.3d 390 (6th Cir. 2009).

39. Id. at 395-94.

40. Id. at 397-99.

41. Id. at 399-400.

42. Id. at 400 . 
officers of the company were involved; ${ }^{43}$ that the company's practices had been investigated by the SEC and Department of Justice, ${ }^{44}$ that an outside law firm had warned that the non-complying voting machines could be rejected by the purchasers; ${ }^{45}$ and that the company had offered no satisfactory explanation for its accounting practices that did not involve fraud. ${ }^{46}$ These allegations, individually or in tandem, were deemed insufficient to satisfy the Tellabs standard. ${ }^{47}$ One can agree that these allegations did not establish a clear case of fraud; but, taken as a whole, they did create grounds for suspicion. The case may have been a loser at trial, but it was far from frivolous.

In Matrix Capital Management Fund, LP v. BearingPoint, Inc., ${ }^{48}$ the corporate defendant made numerous inaccurate accounting disclosures over an extended period of time. ${ }^{49}$ Plaintiffs alleged that the company's financial reporting system was notoriously unreliable and that the individual defendants, by virtue of their positions in the firm, must have known this fact. ${ }^{50}$ It was uncontested, moreover, that the company had significantly overstated net income and other financial data. All told, the company over-reported net income by close to $\$ 100$ million and had to spend that much in investigating and correcting the problem. A consultant found that every one of twenty to thirty contracts he reviewed was incorrect in some material way. ${ }^{51}$ The SEC launched an investigation and subpoenaed records. And the company had a significant motive to overstate results: it was seeking to sell $\$ 450$ million in debentures. ${ }^{52}$ These allegations of scienter were not overwhelming. There was no smoking gun. The allegations might even be considered weak. But frivolous they were not.

These and other cases demonstrate that Tellabs does more than eliminate frivolous cases. It also weeds out cases where the allegations of scienter are not strong, but where, with the benefit of discovery, the plaintiff might be able to establish the requisite state of mind at trial. To evaluate the cost of this type of error, it is necessary to determine whether and to what extent we value allowing weak but nonfrivolous cases into the litigation system. In general, American law favors letting people have their day in court, even if their chances of winning are not high. ${ }^{53}$ Further, given the importance of private securities litigation in

43. Id. at 400-01.

44. Id. at 401-02.

45. Id. at 403 .

46. Id.

47. Id. at 404 .

48. 576 F.3d 172 (4th Cir. 2009).

49. Id. at $177-79$.

50. Id. at 185 .

51. $I d$.

52. Id.

53. See Richards v. Jefferson Cnty., Ala., 517 U.S. 793, 798 (1996) (quoting 18 C. WRIGHT, A. Miller, \& E. COOPER, Federal PRACTICE AND PROCEDURE $\S 4449$, at 417 (1981) (referring to the "deep-rooted historic tradition that everyone should have his own day in court")). 
protecting investors and informing markets, it does not seem particularly desirable to eliminate potentially meritorious litigation merely because the plaintiff, lacking the evidence that can be obtained through discovery, is unable to proffer facts at the pleading stage that establish the requisite inference of scienter. It appears, therefore, that the Tellabs rule imposes a significant cost on society insofar as it screens out potentially meritorious claims. ${ }^{54}$

IV

\section{A MODEST PROPOSAL}

The foregoing suggests reasons for concern that the strong inference standard, as articulated by Congress and as refined in Tellabs, imposes excessive demands on plaintiffs and thereby generates an undesirable level of error by cutting off potentially meritorious cases or deterring people from bringing such cases in the first place. This conclusion raises the issue of whether there are other, better ways to accomplish the screening function.

One approach could be to modify the Tellabs standard-for example, by adopting the "bifurcated" interpretation mentioned above, which would generate more plaintiff-friendly results than the unitary standard. Such a reform might go part of the way to reducing the error costs of screening out meritorious cases. Statutory modifications that would lighten the burden on plaintiffs could also be imagined-for example, Congress might permit limited discovery pertinent to scienter prior to a ruling on the motion to dismiss if the plaintiff establishes substantial hardship in obtaining the information through other means. This section explores a different approach-one that is unlikely to be implemented but that may be worth consideration as a way to enrich the options for reform available within the policy space.

Here's the idea. As under current practice, the defendant could move to dismiss the complaint on the ground that the plaintiff has not set forth detailed allegations creating a strong inference of scienter. The court would grant the motion and tentatively dismiss the complaint if, assuming that the facts alleged in the complaint were the only ones proved at trial, the plaintiff would not establish an inference of scienter that is at least as strong as the inference that the defendant did not act with scienter. However, if the plaintiff disagrees with the order after reviewing the court's reasoning, she would have a reasonable

54. The Tellabs standard creates difficulties other than its potential to weed out meritorious cases. Because plaintiffs are denied discovery prior to the ruling on motion to dismiss, there is a significant premium on private investigation. This creates four costs. First, because potential defendants are not required to comply with the inquiries of private investigators and, in fact, are likely to affirmatively resist accommodating such people, the cost of finding information from this source is likely to be higher than the cost of discovery. Second, the cost of private investigation will be duplicative if the complaint survives a motion to dismiss and the plaintiffs then seek discovery of information that overlaps with what the investigators found. Third, private investigation is intrusive on privacy and potentially disruptive to company morale. Finally, because private investigation imposes a substantial upfront cost on plaintiffs' attorneys, the PSLRA's denial of discovery until after the motion to dismiss operates as a de facto entry barrier to the plaintiffs' bar: unless a plaintiffs' firm is large and well-funded, it may find the costs of investigation to be outside its financial reach. 
period of time to file an objection. Once such an objection is filed, the order dismissing the complaint would be vacated and the litigation would proceed to discovery. If, however, the defendant thereafter wins summary judgment on the issue of scienter, the defendant would be entitled to be reimbursed for his reasonable post-dismissal counsel fees.

The tentative dismissal idea compares well with current law under Tellabs and the PSLRA. First, it does not create a danger that frivolous cases will go forward. It is true that a plaintiff in a frivolous case who disagrees with a court's tentative dismissal could file an objection and thereafter litigate the case as if the order had never been given. But the plaintiff would then face the risk of having to pay defendant's post-dismissal fees in the event that the court grants summary judgment to the defendant on the issue of scienter. Few attorneys would want to take on this risk if their cases were truly frivolous.

The tentative dismissal idea is also superior in regard to the danger that good cases will be weeded out. Plaintiffs' attorneys who believe their cases to be well founded have the option, after experiencing a tentative dismissal, either to drop the case or to go forward into discovery. If they drop the case, they are no worse off than under current law. If they decide to go forward, they have the chance to discover facts establishing the defendant's scienter, and may wind up winning a favorable settlement or judgment at trial. In this respect, the error costs of weeding out meritorious cases are significantly reduced.

Would a plaintiff's counsel ever take on the risk of proceeding knowing that, if he loses a summary judgment motion on the issue of scienter, the plaintiff will be responsible for paying the defendant's reasonable post-dismissal fees? There are several reasons to suppose that he would. The summary judgment standard is not demanding; the plaintiff merely needs to establish that a reasonable finder of fact could find in his favor on the issue of scienter. If counsel believes that his case is well founded, he may elect to incur the risk simply because he thinks it is unlikely to materialize. If discovery does not generate the expected evidence of scienter, counsel could drop a case before the summary judgment stage and thus avoid liability for the defendant's post-dismissal fees (although this may be complicated if a class has been certified). Litigation insurance might also be available to protect counsel against the risk of having to pay the defendant's fees.

For all these reasons, cases that would not go forward under existing law would go forward under a tentative dismissal regime. In consequence, the tentative dismissal idea holds promise to perform the filtering function with lower error costs. ${ }^{55}$

55. The tentative dismissal idea would also respond to the argument that heightened pleading standards unconstitutionally interfere with the exercise of Seventh Amendment jury-trial rights. See Suja A. Thomas, Why the Motion to Dismiss is Now Unconstitutional, 92 MINN. L. REV. 1851, 1879-82 (2008). 


\section{$\mathrm{V}$ \\ CONCLUSION}

Private securities fraud litigation is one means by which the legal system polices the integrity of securities markets and ensures that information flowing in those markets is accurate and not deceptive. Without private liability, wrongdoers would be freer to disseminate falsehoods in the market in order to profit from the resulting price distortions. Thus, private securities fraud litigation serves important public policies.

On the other hand, securities fraud litigation is costly. Companies (or their insurers) sued for securities fraud expend millions of dollars in defending themselves against liability and in complying with the demands of discoverymoney that, if not expended on litigation, could be used to improve the quality of or reduce the cost of the products these companies sell. Such litigation also imposes burdens on the court system and the taxpayers. And, if the reach of liability extends too far-if persons not guilty of any misconduct are forced to pay substantial damages in order to avoid the risk of an erroneous decisionthen securities fraud litigation could impair the willingness of corporate actors to undertake socially desirable risks.

Pleading rules under the PSLRA are filters designed to optimize the publicpolicy tradeoffs. As interpreted in Tellabs, the filter established in the PSLRA does an admirable job of rejecting frivolous cases. But the filter also weeds out too many cases that should be allowed to proceed. The consequence is that, in the name of curbing abusive litigation, the statute shelters efforts by corporations and corporate managers to deceive investors and distort market prices.

A better approach is the tentative dismissal. A plaintiff who suffers a dismissal for failing to plead specific facts giving rise to a strong inference of scienter would be able to obtain relief from that order, but only if the plaintiff or plaintiff's counsel assumes liability to pay the defendant's reasonable postdismissal attorneys' fees in the event the court grants the defendant's later motion for summary judgment on the issue of scienter. This approach would allow meritorious cases to go forward without creating an undue risk of frivolous litigation. The proposal is not likely to be implemented any time soon, but it is worthy of consideration as a contribution to the range of options available for regulating the volume and substance of securities fraud litigation. 